\title{
OPTIONS FOR ABATING GREENHOUSE GASES FROM EXHAUST STREAMS
}

Vasilis Fthenakis

December 7, 2001

\section{BRDOKHDLEN \\ NATIONAL LABORATORY}

\author{
Environmental Sciences Department \\ Brookhaven National Laboratory \\ Brookhaven Science Associates \\ Upton, Long Island New York 11973
}

Under Contract No. DE-AC02-98CH10886 with the

UNITED STATES DEPARTMENT OF ENERGY 


\section{DISCLAIMER}

This report was prepared as an account of work sponsored by an agency of the United States Government. Neither the United State Government nor any agency thereof, nor any of their employees, not any of their contractors, subcontractors, or their employees, makes any warranty, express or implied, or assumes any legal liability or responsibility for the accuracy, completeness, or usefulness of any information, apparatus, product, or process disclosed, or represents that its use would not infringe privately owned rights. Reference herein to any specific commercial product, process, or service by trade name, trademark, manufacturer, or otherwise, does not necessarily constitute or imply its endorsement, recommendation, or favoring by the United States Government or any agency, contractor, or subcontractor thereof. The views and opinions of authors expressed herein do not necessarily state or reflect those of the United States Government or any agency, contractor or subcontractor thereof. 


\title{
Options for Abating Greenhouse Gases from Exhaust Streams*
}

\author{
Vasilis Fthenakis \\ Environmental Sciences Department \\ Brookhaven National Laboratory \\ Upton, NY 11973
}

\begin{abstract}
This report examines different alternatives for replacing, treating, and recycling greenhouse gases. It is concluded that treatment (abatement) is the only viable short-term option. Three options for abatement that were tested for use in semiconductor facilities are reviewed, and their performance and costs compared. This study shows that effective abatement options are available to the photovoltaic (PV) industry, at reasonable cost.
\end{abstract}

* This work was performed under the auspices of the U.S. Department of Energy. 


\section{TABLE OF CONTENTS}

ABSTRACT

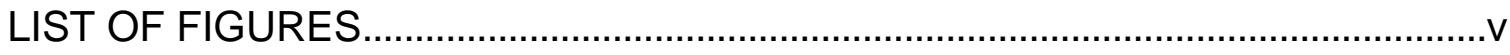

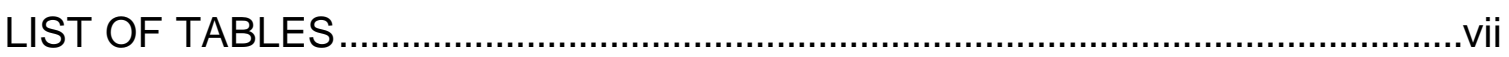

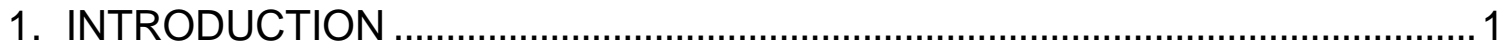

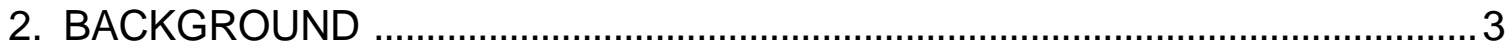

3. REVIEW OF ALTERNATIVES …................................................................. 5

3.1 Substitution........................................................................................... 5

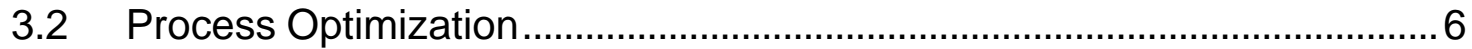

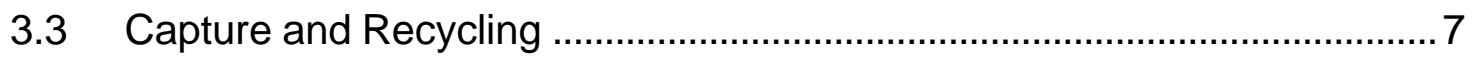

3.4 Abatement of PFCs from Emission Streams ........................................... 7

4. COMMERCIAL POINT-OF-USE ABATEMENT SYSTEMS ............................. 8

4.1. The BOC Edwards Thermal Processing System .................................... 8

4.2 Plasma Abatement Systems ................................................................. 9

4.2.1 Evaluation of the Litmas Plasma System .......................................10

4.3 Catalytic Decomposition Systems ........................................................12

4.3.1 Evaluation of the Hitachi ThermoCatalytic Decomposition

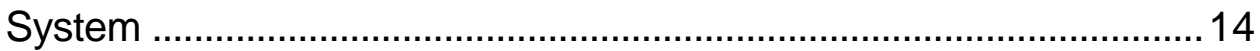

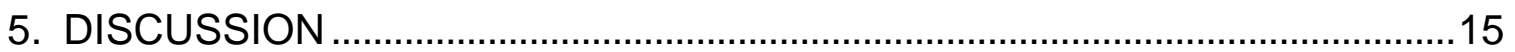

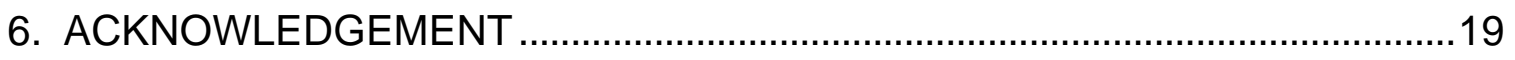

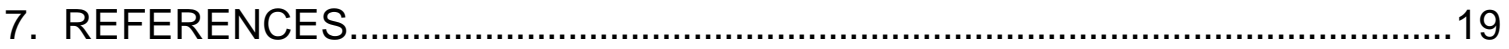




\section{LIST OF FIGURES}

Figure 1. Comparison of different gases in chamber cleaning …........................... 5

Figure 2. A schematic of the NF3 remote system for chamber cleaning ............... 6

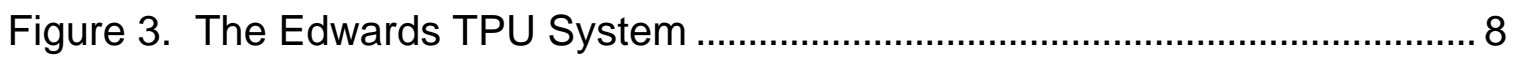

Figure 4. The Litmas PFC plasma abatement device ...........................................10

Figure 5. Configuration of plasma PFC abatement system ................................10

Figure 6. A schematic of ThermoCatalytic PFC abatement systems ................... 13

Figure 7. The Hitachi ThermoCatalytic Abatement System ................................. 14 


\section{LIST OF TABLES}

Table 1. Characteristics of Some Common Etching Compounds .......................... 2

Table 2. Atmospheric Lifetimes and Global Warming Potentials (GWPs) of Selected Greenhouse Gases .................................................................. 4

Table 3. Summary Comparison of PFT Abatement Systems ..............................17 


\section{INTRODUCTION}

Currently, only a subgroup of the Si photovoltaic industry uses greenhouse gases. Carbon tetrafluoride $\left(\mathrm{CF}_{4}\right)$ is used in plasma ("dry") etching of silicon wafers and trichloroethane (TCA) for cleaning tubes in phosphorous diffusion. In planned, large-scale manufacturing facilities, greenhouse gases also may be used to clean deposition chambers.

Dry etching is a method that is much safer than wet etching because the process is confined and the effluents are directly exhausted without the operators normally being exposed to them. Some safety and health issues associated with accidental exposures to the byproducts of the dry process were addressed in an earlier report (Fthenakis and Moskowitz, 1995). This report focuses on greenhouse gases only. In the plasma etching of silicon compounds, gases containing fluoride and chloride species are commonly used (e.g., $\mathrm{HF}, \mathrm{HCl}, \mathrm{CF}_{4}$, $\mathrm{CCl}_{4}, \mathrm{C}_{2} \mathrm{~F}_{6}, \mathrm{CCl}_{2} \mathrm{~F}_{2}, \mathrm{SF}_{6}$, and $\mathrm{NF}_{3}$; Table 1). The etching byproducts include $\mathrm{F}_{2}$ and $\mathrm{HF}, \mathrm{Cl}_{2}$ and $\mathrm{HCl}$, and fluorinated or chlorinated compounds of the material being etched.

Conceivably, many compounds may be formed by the highly energetic ions in a plasma environment. For example, gaseous effluents from etching operations with carbon tetrachloride include carbon tetrachloride, perchloroethylene, trichloroethylene, trichloroethane, hexachloroethane, hexachlorobenzene, hexachloro- butadiene, methylene chloride, and free fluorides (Fthenakis and Moskowitz, 1995). 
Table 1. Characteristics of Some Common Etching Compounds

\begin{tabular}{|c|c|c|c|c|c|}
\hline Compound & $\begin{array}{l}\text { State in } \\
\text { Cylinder }\end{array}$ & \begin{tabular}{|l} 
Cylinder \\
Pressure \\
(psig)@ $@ 70^{\circ} \mathrm{F}$
\end{tabular} & $\begin{array}{l}\mathrm{PEL} / \mathrm{TLV}^{1} \\
\text { (ppm) }\end{array}$ & $\begin{array}{l}\text { IDLH }^{2} \\
\text { (ppm) }\end{array}$ & Comments \\
\hline $\mathrm{F}_{2}$ & Gas & 300 & $\overline{1}$ & 25 & $\begin{array}{l}\text { Highly toxic, } \\
\text { oxidizer }\end{array}$ \\
\hline $\mathrm{Cl}_{2}$ & $\begin{array}{l}\text { Liquefied } \\
\text { gas }\end{array}$ & $85.3^{*}$ & 0.5 & 25 & $\begin{array}{l}\text { Corrosive, } \\
\text { strong oxidizer }\end{array}$ \\
\hline $\mathrm{NF}_{3}$ & $\begin{array}{l}\text { Compressed } \\
\text { gas }\end{array}$ & $800-1450$ & 10 & 2000 & Toxic, oxidizer \\
\hline $\mathrm{CF}_{4}$ & $\begin{array}{l}\text { Compressed } \\
\text { gas }\end{array}$ & $500-2000$ & & & Greenhouse gas \\
\hline $\mathrm{C}_{2} \mathrm{~F}_{6}$ & & & & & Greenhouse gas \\
\hline $\mathrm{C}_{4} \mathrm{~F}_{8}$ & & & & & Greenhouse gas \\
\hline $\mathrm{C}_{5} \mathrm{~F}_{8}$ & & & & & $\begin{array}{l}\text { Toxic, } \\
\text { greenhouse gas }\end{array}$ \\
\hline $\mathrm{CCl}_{4}$ & Liquid & & 10 & 300 & $\begin{array}{l}\text { Toxic, suspected } \\
\text { carcinogen }\end{array}$ \\
\hline $\mathrm{SF}_{6}$ & $\begin{array}{l}\text { Liquefied } \\
\text { gas }\end{array}$ & $300^{*}$ & & & Greenhouse gas \\
\hline $\begin{array}{l}\mathrm{SF}_{6} \text { in } \\
\mathrm{He} / \mathrm{N}_{2}\end{array}$ & $\begin{array}{l}\text { Compressed } \\
\text { gas }\end{array}$ & 2000 & & & Greenhouse gas \\
\hline $\mathrm{HF}$ & $\begin{array}{l}\text { Liquefied } \\
\text { gas }\end{array}$ & $0.6^{*}$ & 3 & 30 & Toxic, corrosive \\
\hline $\mathrm{HCl}$ & $\begin{array}{l}\text { Liquefied } \\
\text { gas }\end{array}$ & $613^{*}$ & 5 & 100 & Toxic, corrosive \\
\hline $\mathrm{BF}_{3}$ & $\begin{array}{l}\text { Compressed } \\
\text { gas }\end{array}$ & 2000 & 1 & 100 & Toxic, corrosive \\
\hline $\mathrm{BCl}_{3}$ & $\begin{array}{l}\text { Liquefied } \\
\text { gas }\end{array}$ & $4.4^{*}$ & 5 & 100 & Toxic, corrosive \\
\hline $\begin{array}{l}\mathrm{CClF}_{3} \\
\text { (Freon-13) }\end{array}$ & $\begin{array}{l}\text { Liquefied } \\
\text { gas }\end{array}$ & 458 & & & $\begin{array}{l}\text { Ozone depletion, } \\
\text { greenhouse gas }\end{array}$ \\
\hline $\begin{array}{l}\mathrm{CCl}_{2} \mathrm{~F}_{2} \\
\text { (Freon-12) }\end{array}$ & $\begin{array}{l}\text { Liquefied } \\
\text { gas }\end{array}$ & 70.2 & & & $\begin{array}{l}\text { Ozone depletion, } \\
\text { greenhouse gas }\end{array}$ \\
\hline
\end{tabular}

${ }^{*}$ This is the vapor pressure of the compound at $70^{\circ} \mathrm{F}\left(21^{\circ} \mathrm{C}\right)$.

${ }^{1} \mathrm{PEL} / \mathrm{TLV}=$ Permissible Exposure Limit/ Threshold Limit Value - It represents time-weighted average concentration for work-shift (40-hr week) employee protection.

${ }^{2}$ IDLH $=$ Immediately Dangerous to Life and Health - It represents maximum concentration from which a healthy adult could escape after a 30-minute exposure without any symptoms that would impair escape, or cause any irreversible health effects. 


\section{BACKGROUND}

Perfluorocarbons (PFCs), hydrofluorocarbons (HFCs), sulfur hexachloride $\left(\mathrm{SF}_{6}\right)$, and nitrogen trifluoride $\left(\mathrm{NF}_{3}\right)$ have been identified as potential, global-warming gases because of their characteristics of strong infrared (IR) absorption and very long atmospheric lifetimes. Carbon dioxide accounts for the largest share of global-warming gases in the earth's atmosphere ( $80 \%)$, while PFCs make up only $2 \%$ of the global total of such gases. However, when rated against $\mathrm{CO}_{2}$, which was given an arbitrary global-warming-potential value of one, PFCs have potential values that are thousands to tens of thousands of times higher. Table 2 lists the atmospheric lifetimes of selected greenhouse gases and their globalwarming potentials over a 100-year period $\left(G_{W P} P_{100}\right)$, and over their lifetimes

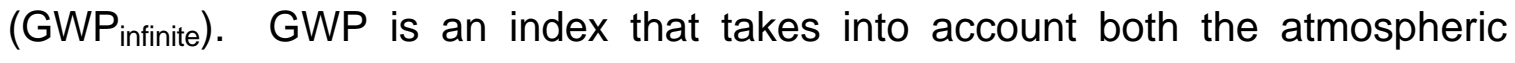
lifetime of a chemical and its IR absorption spectrum in comparison to those of $\mathrm{CO}_{2}$. It shows the time-integrated warming effect caused from a release of a unit mass of a PFC gas in today's atmosphere, relative to that from $1 \mathrm{~kg}$ of $\mathrm{CO}_{2}$. For example, $1 \mathrm{~kg}$ of $\mathrm{CF}_{4}$ can produce the same amount of global warming during 100 years as do 6,300 or $10,900 \mathrm{~kg}$ of $\mathrm{CO}_{2}$; hence, $\mathrm{CF}_{4}$ has a $\mathrm{GWP}_{100}$ of 6,300 or 10,900 .

Because of their potential, long-term impact on the global climate, international efforts are being made to reduce the emissions of PFCs, HFCs, and $\mathrm{SF}_{6}$ (e.g., The Kyoto Protocol). Furthermore, the U.S. semiconductor industry is committed to voluntarily reducing PFC emissions over the next decade and has embarked upon research and technical studies of the feasibility of different options. These studies provided major input to this report. 


\section{Table 2. Atmospheric Lifetimes and Global Warming Potentials (GWPs) of Selected Greenhouse Gases}

\begin{tabular}{|l|c|c|c|}
\hline PFC/HFC & Lifetimes $^{(1)}(\mathbf{y r s})$ & GWP $_{\mathbf{1 0 0}}{ }^{(2)}$ & GWP $_{\text {Infinite }}{ }^{(6)}$ \\
\hline $\mathrm{CO}_{2}$ & $200^{(5)}$ & 1 & 1 \\
\hline $\mathrm{CH}_{4}$ & 10 & 11 & \\
\hline $\mathrm{CF}_{4}$ & $5.0 \times 10^{(4)}$ & $10,900^{(4)} ; 6,300^{(5)} ;$ & 850,000 \\
\hline $\mathrm{CHF}_{3}$ & $250^{(5)}$ & 12,100 & 11,000 \\
\hline $\mathrm{CH}_{2} \mathrm{~F}_{2}$ & & 580 & 230,000 \\
\hline $\mathrm{C}_{2} \mathrm{~F}_{6}$ & $>1.0 \times 10^{4}$ & 12,$500 ; 9200^{(5)}$ & 130,000 \\
\hline $\mathrm{C}_{3} \mathrm{~F}_{8}$ & $2,600^{(5)}$ & $7,000^{(5)}$ & \\
\hline $\mathrm{C}_{4} \mathrm{~F}_{8}$ & $3.2 \times 10^{3}$ & 9,100 & 230,000 \\
\hline $\mathrm{SF}_{6}$ & $3.2 \times 10^{3}$ & $21,000^{(4)} ; 23,900^{(5)}$ & 18,000 \\
\hline $\mathrm{NF}_{3}$ & $<179^{(3)}, 740^{(5)}$ & $24,200^{(3)} ; 13,100^{(5)} ; 8,000^{(6)}$ & \\
\hline
\end{tabular}

1 "Best estimate" values of Ravishankara, 1993, unless listed otherwise.

${ }^{2} \mathrm{GWP}_{100}$ is the Global Warming Potential, relative to $\mathrm{CO}_{2}$, over 100 years.

${ }^{3}$ Estimates of Air Products Inc. listed in Martinelli, 1994.

4 Abrahamson D. et al., 1991; Ko M. et al., 1998, listed in Martinelli, 1994

${ }^{5}$ Gompel and Walling, 1997

${ }^{6} \mathrm{GWP}$ Infinite is the Global Warming Potential, relative to $\mathrm{CO}_{2}$, over the lifetime of the gas; values from Worth (2001)

The major source of $\mathrm{SF}_{6}$ is from leaking insulated electrical equipment. The most significant anthopogenic source of $\mathrm{CF}_{4}$ and $\mathrm{C}_{2} \mathrm{~F}_{6}$ is aluminum smelting. The semiconductor industry's use of PFCs is very small in comparison with the amounts released by the aluminum smelting industry; their uncontrolled emissions in 1999 accounted for approximately 5\% of the PFC emissions in the United States, equivalent to $0.1 \%$ of the global-warming gases in the earth's atmosphere. Although this percentage may seem trivial, the semiconductor industry's PFC emissions nearly tripled between 1990 and 1999, and a steady increase is expected to continue as the industry continues to expand. 


\section{REVIEW OF ALTERNATIVES}

There are four prevention and control strategies to reduce emissions of greenhouse gases: substitution, process optimization, capture and recycling, and abatement.

\subsection{Substitution}

The semiconductor industry has examined the use of alternatives to PFCs that are not greenhouse gases and greenhouse gases that are used more efficiently. No benign alternatives were found. Related to better utilization, Allgood et al. (2000) evaluated the performance of four gas mixtures in chamber cleaning; they were $\mathrm{C}_{2} \mathrm{~F}_{6}$ in $\mathrm{O}_{2}, \mathrm{C}_{3} \mathrm{~F}_{8}$ in $\mathrm{O}_{2}, \mathrm{C}_{4} \mathrm{~F}_{8}$ in $\mathrm{O}_{2}$, and $\mathrm{NF}_{3}$ in He (Figure 1). Comparisons were made of cleaning rates, carbon-equivalent PFC emissions, and gas utilization. For the fluorocarbon gases, performance increased with increasing molecular weight, with $\mathrm{C}_{4} \mathrm{~F}_{8}$ showing the best process performance of the PFCs, and $\mathrm{NF}_{3}$ being best overall. $\mathrm{NF}_{3}$ showed a $90-99 \%$ utilization rate, whereas only $30-40 \%$ of the PFCs were utilized. In another study (Mendicino, 1998), an $\mathrm{NF}_{3}$ Remote Clean $^{\mathrm{TM}}$ was used for chamber cleaning during processing of 13,000 wafers, with no evidence of particle generation and no adverse effects on manufacturing and film processes. A schematic of this system is shown in Figure 2.

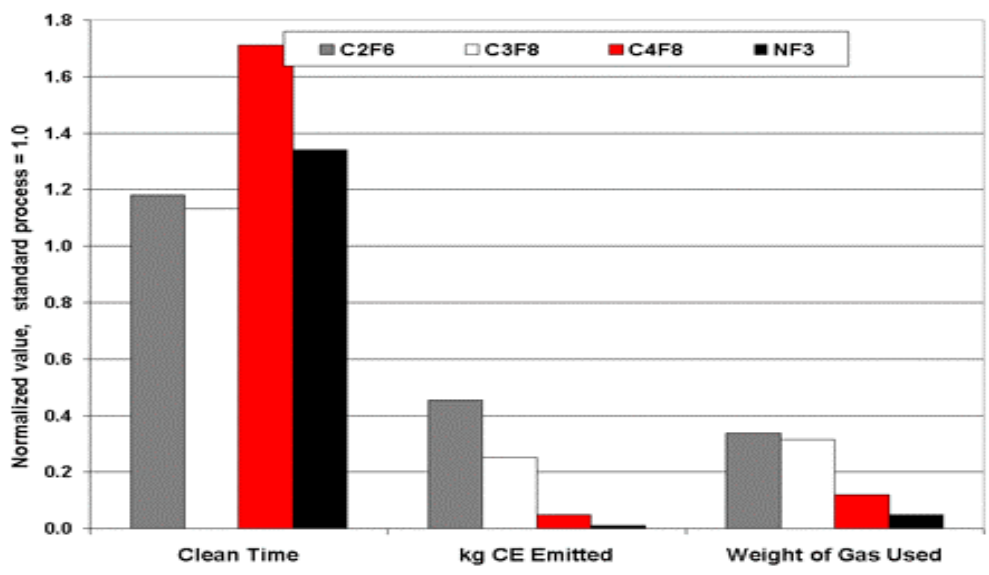

Figure 1. Comparison of different gases in chamber cleaning 


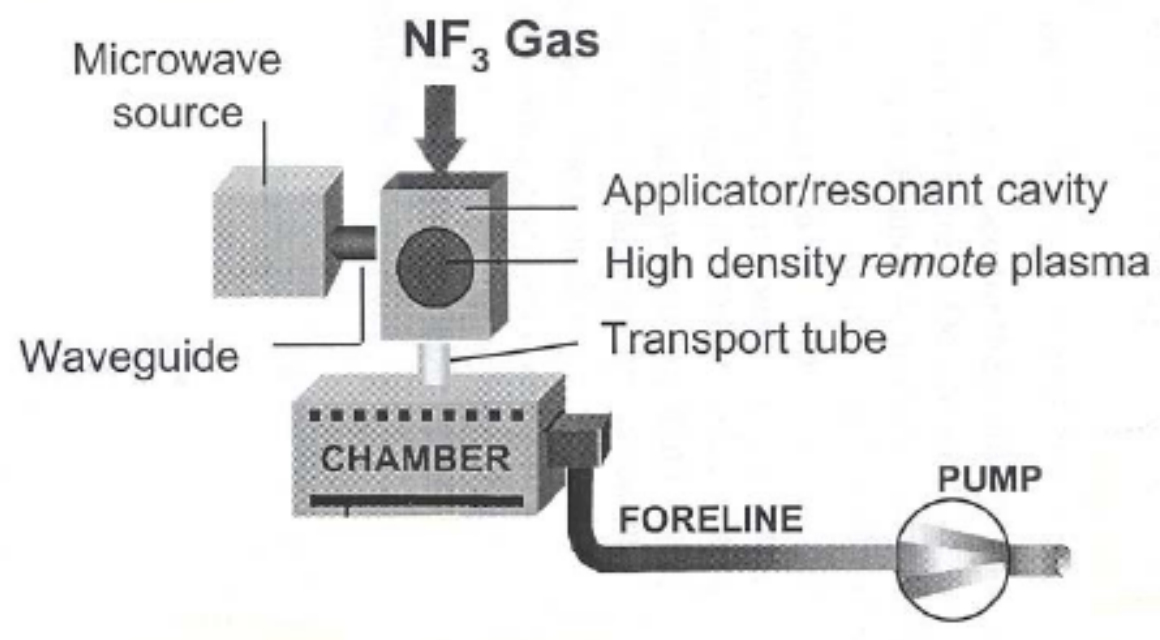

Figure 2. A schematic of the NF3 remote system for chamber cleaning

$\mathrm{NF}_{3}$ cuts down greenhouse emissions by a factor of 10 to 100 by comparison with PFC chamber cleaning operations. On the negative side, adding a $\mathrm{NF}_{3}$ Remote Clean ${ }^{\mathrm{TM}}$ plasma system costs $\sim \$ 60,000$, and $\mathrm{NF}_{3}$ costs $4-5$ times more than the least expensive clean gas $\mathrm{C}_{2} \mathrm{~F}_{6}$ (i.e., $\mathrm{C}_{2} \mathrm{~F}_{6} @$ @ $25 / \mathrm{lb}, \mathrm{NF}_{3} @ \$ 110 / \mathrm{lb}$ ). $\mathrm{NF}_{3}$ also produces higher $\mathrm{F}_{2}$ emissions than PFCs.

Viable alternatives to $\mathrm{CF}_{4}$ for etching applications have not been found.

\subsection{Process Optimization}

Many etching or cleaning processes use only $30-40 \%$ of the PFCs delivered to the process; therefore, optimizing the etching/cleaning processes can significantly lower emissions. Johnson et al. (2000) reported that optimization of $\mathrm{C}_{2} \mathrm{~F}_{6}$ plasma cleaning of a Plasma Enhanced Chemical Vapor Deposition (PECVD) chamber reduced PFC emissions by $75 \%$. Beatty et al. (2000) used $\mathrm{C}_{3} \mathrm{~F}_{8}$ instead of $\mathrm{C}_{2} \mathrm{~F}_{6}$ as the chamber-cleaning gas of a PECVD reactor and obtained an $18 \%$ reduction of $\mathrm{CF}_{4}$ emissions and a $40 \%$ reduction of other PFC emissions. 
While process optimization can substantially reduce emissions, it cannot by itself eliminate the problem. Furthermore, no optimization of $\mathrm{CF}_{4}$-based plasma processes is reported in the literature.

\subsection{Capture and Recycling}

Techniques for capturing PFCs from exhaust streams by membrane separation, adsorption, absorption, and condensation were reported to have limited efficiency. Capture and recycling is complicated because emissions from chamber-cleaning operations, and, to a lesser degree, from etching operations, carry a large number of species and particulates. Therefore, pretreatment and a series of separations are necessary to recover PFCs.

Early results of membrane-based separation showed $>98 \%$ efficiency, but at a relatively high cost (Cummins et al., 1998). Testing of a cryogenic separation unit showed $>99 \%$ efficiency for $\mathrm{C}_{2} \mathrm{~F}_{6}, \mathrm{CHF}_{3}$, and $\mathrm{SF}_{6}$, but only $\sim 75 \%$ for $\mathrm{CF}_{4}$ (Gilliland and Hoover, 1998); also, this separation was costly (e.g., $\$ 500 \mathrm{~K}$ installation cost for a 200 scfm unit)

Kelly (2001) recently described a method of condensing mixtures of PFCs where $\mathrm{CF}_{4}$ is used as solvent for the heavier PFCs. $\mathrm{CF}_{4}, \mathrm{CHF}_{3}, \mathrm{C}_{3} \mathrm{~F}_{8}, \mathrm{C}_{2} \mathrm{~F}_{6}$, and $\mathrm{SF}_{6}$ at concentrations (in $\mathrm{N}_{2}$ ) of $4,000 \mathrm{ppm}$ to $24,000 \mathrm{ppm}$ were captured at efficiencies of $>99.7 \%$ as liquid condensate. The cost and commercial feasibility of this option was not reported.

\subsection{Abatement of PFCs from Emission Streams}

Abatement can be used for both etching and chamber-cleaning operations. Early PFC abatement systems were not effective in destroying $\mathrm{CF}_{4}$, because of its strong $\mathrm{C}-\mathrm{F}$ molecular bonds. Burn boxes operating at temperatures of $800{ }^{\circ} \mathrm{C}$ were only up to $27 \%$ effective in destroying PFCs (Beatty et. al, 2000). Many times the destruction of $\mathrm{CHF}_{3}, \mathrm{C}_{2} \mathrm{~F}_{6}$, and $\mathrm{C}_{3} \mathrm{~F}_{8}$ generated $\mathrm{CF}_{4}$ from the decomposition of the original gases. However, some new commercial systems 
have shown very high efficiencies of abating PFCs, including $\mathrm{CF}_{4}$. The following are the commercial abatement systems with the highest tested performance: The Edwards thermal decomposition system, the Litmas plasma system, and the Hitachi thermocatalytic decomposition system. They are described below.

\section{COMMERCIAL POINT-OF-USE ABATEMENT SYSTEMS}

\subsection{The BOC Edwards Thermal Processing System}

The BOC Edwards Thermal Processing Unit (TPU) consists of a combustion device, a scrubber, and a pump, integrated in an enclosed unit (Figure 3).

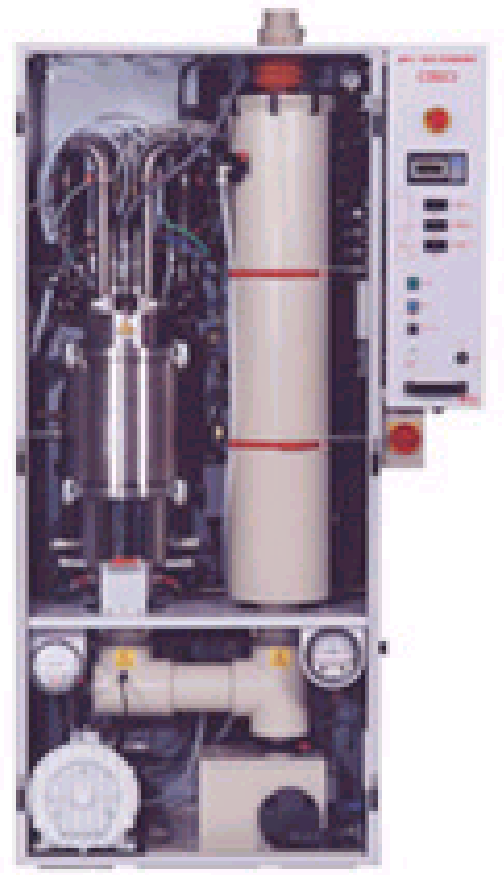

Figure 3. The Edwards TPU System

The TPU can handle up to four streams for a total of 200 standard liters/min (s/mp). The gases are admitted through the inlet lines above the combustor where they are decomposed at temperatures of $800-1100{ }^{\circ} \mathrm{C}$. Then the gases are cooled to ambient temperatures and scrubbed to remove particulates and watersoluble combustion gases. The TPU can be used for streams of different gases in addition to PFCs (e.g., $\mathrm{NH}_{3}, \mathrm{NF}_{3}, \mathrm{~B}_{2} \mathrm{H}_{6}, \mathrm{TMB}, \mathrm{PH}_{3}, \mathrm{GeH}_{4}$, and $\mathrm{WF}_{6}$ ). Early models were not effective in decomposing $\mathrm{CF}_{4}$ although they were highly efficient in decomposing other PFCs. A modified TPU showed an abatement effectiveness of $100 \%$ for $\mathrm{C}_{2} \mathrm{~F}_{6}$ and $96 \%$ for $\mathrm{CF}_{4}$, in flows of $50 \mathrm{slpm}$ (for each of four inlet streams), with inlet PFC concentrations ranging from $700 \mathrm{ppm}$ to $4100 \mathrm{ppm}$. Abatement of PFCs required the addition of natural gas to the chamber exhaust gases, whereas $\mathrm{NF}_{3}, \mathrm{~B}_{2} \mathrm{H}_{6}, \mathrm{TMB}, \mathrm{PH}_{3}, \mathrm{GeH}_{4}$, and $\mathrm{WF}_{6}$ were easily abated without adding natural gas (Gompel and Walling, 1997; Walling et al., 1997). The abatement 
performance was monitored with concentration measurements using Fourier transform infrared spectroscopy and mass spectrometry.

The TPU can handle exhausts from up to four processes of $50 \mathrm{slpm}$ each, for a total flow of $200 \mathrm{slpm}$. PFC flows of up to $2 \mathrm{slpm}$ in $48 \mathrm{slpm}$ of $\mathrm{N}_{2}$ were abated at approximately $90 \%$ efficiency, whereas $\mathrm{SiH}_{4}, \mathrm{NF}_{3}, \mathrm{~B}_{2} \mathrm{H}_{6}, \mathrm{TMB}, \mathrm{PH}_{3}, \mathrm{GeH}_{4}$, and $\mathrm{WF}_{6}$ at $0.5 \mathrm{slpm}$ in $\mathrm{N}_{2}$ were diminished at $>99.99 \%$ efficiency.

The manufacturer's listed capital cost for this unit is $\$ 130,000$; other costs are shown in Table 3. Walling et al. (1997) calculated a 5-year cost of ownership of $\$ 77 \mathrm{~K} / \mathrm{yr}$, based on a continuous operation. In a tested model, a water flow of 6-8 gpm was required for cooling and for the high efficiency scrubbing needed to remove HF from the gas stream out of the combustor. Recently, Edwards introduced new systems that clean, chill, and recirculate water, thereby reducing water consumption down to $1.5 \mathrm{gpm}$. At this rate of water flow, the TPU's postreaction scrubber can lower the concentration of HF down to about $20 \mathrm{ppm}$. More water is required if higher scrubbing efficiencies are required; alternatively, the emissions from the TPU could be fed into a "house scrubber" for further treatment.

\subsection{Plasma Abatement Systems}

Another promising method for abating emissions of PFCs and HFCs from etching operations is plasma destruction. These units are relatively small and are not suitable for dealing with high-flow-rate emissions from chamber-cleaning operations. Plasma systems manufactured by Litmas Inc. and by Astron Inc. are reported in the literature. The first, which was tested by Sematech (Tonnis et al., 1999), is described in detail below. Limited information exists on the second one; it is reported to have effectiveness of $98 \%$ in treating $\mathrm{CF}_{4}$ flows of $0.25 \mathrm{slpm}$ using a mixture of $\mathrm{O}_{2}$ and $\mathrm{H}_{2}$ as reactants (Chen et al., 2000). 


\subsubsection{Evaluation of the Litmas Plasma System}

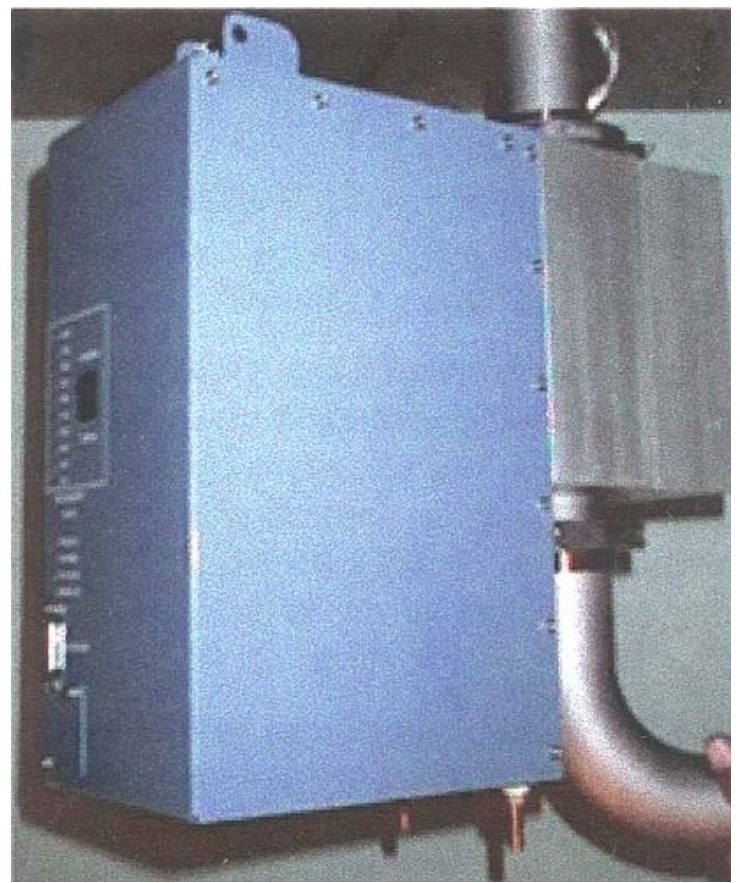

A Litmas plasma abatement system uses a small plasma source located after the etching tool between the turbo pump and the dry pump (Figure 4). A supplementary reactive gas (e.g., $\mathrm{H}_{2}, \mathrm{O}_{2}, \mathrm{H}_{2} \mathrm{O}$, or $\mathrm{CH}_{4}$ ) is added upstream of the plasma-abatement device (Figure 5). This gas and the PFC or HFC are dissociated in the highly energetic plasma and the resulting byproducts are removed in wet scrubbers. A separate plasma device is needed for each PFC-carrying stream.

Figure 4. The Litmas PFC plasma abatement device

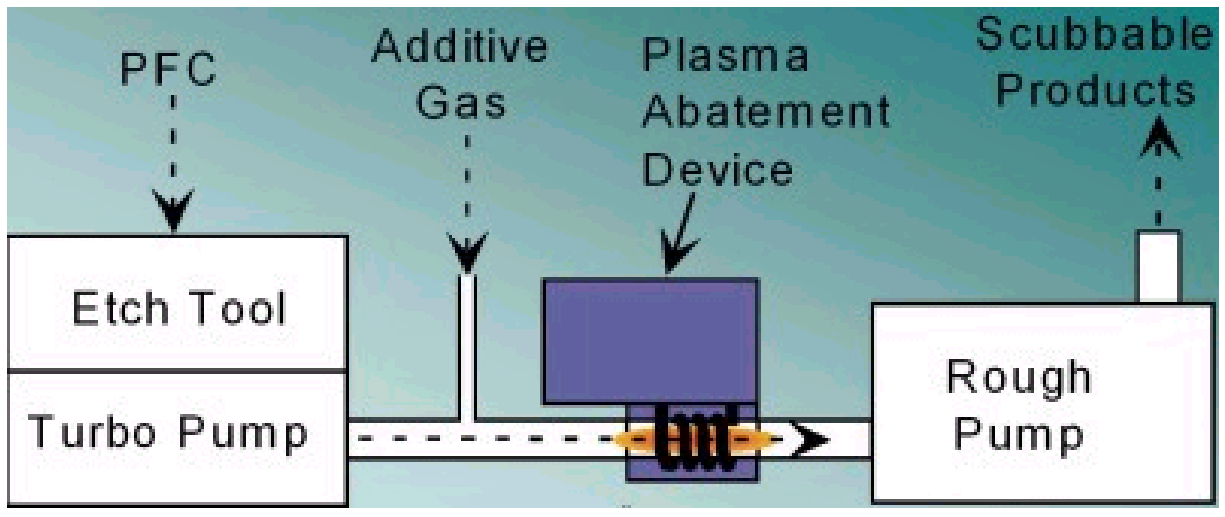

Figure 5. Configuration of a plasma PFC abatement system

The performance of a Litmas "Blue" device was tested in treating emissions from an oxide etcher (Tonnis et al., 1999). Abatement was measured for different parameters of power and materials, using Fourier transform infrared spectroscopy, and mass spectrometry. Average efficiencies of $95 \%$ or higher 
were measured under all conditions. Using $\mathrm{O}_{2}$ as an abatement additive gas, the Litmas "Blue" reduced such emissions by $98.5 \%$ using $1050 \mathrm{~W}$ of plasma input power. In most cases, $\mathrm{CF}_{4}$ was destroyed with an efficiency of $96 \%$, while the concentration of $\mathrm{CHF}_{3}$ was lowered to below detectable levels $(>99.5 \%$ abatement).

The primary byproducts (with $\mathrm{O}_{2}$ as an additive gas) included $\mathrm{CO}_{2}, \mathrm{COF}_{2}$, and $\mathrm{HF}$, with traces of $\mathrm{F}_{2}$ and $\mathrm{NO}_{2}$. Water vapor-based plasma abatement reduced greenhouse-gas emissions from the same oxide ether by $99.6 \%$. Its effectiveness for destroying $\mathrm{CF}_{4}$ was $99.3 \%$, and $98.6 \%$ for $\mathrm{CHF}_{3}$. The primary byproducts of water vapor-based abatement included HF and $\mathrm{CO}$ with trace formation of $\mathrm{CO}_{2}$ and of $\mathrm{COF}_{2}, \mathrm{NO}_{2}$, and $\mathrm{F}_{2}$. The flow rates in these experiments were only 4-6 sccm of $\mathrm{CF}_{4}, 50-60 \mathrm{sccm}$ of $\mathrm{CHF}_{3}$, and 50-70 sccm of Ar. These efficiencies decreased with increasing amounts of $\mathrm{CF}_{4}$ and decreasing Ar flow rates. At $100 \mathrm{sccm}$ of $\mathrm{CF}_{4}$, with no Ar, efficiency was $90.7 \%$, which increased to $92.3 \%$ with $50 \mathrm{sccm}$ of $\mathrm{Ar}$, and to $95.7 \%$ with $200 \mathrm{sccm}$ of $\mathrm{Ar}$.

Placing a plasma-abatement system between the process chamber and the dry pumps restricts the diameter of the foreline in the plasma discharge unit. Also, all PFC byproducts are transferred through the downstream dry pump; this creates concerns about the effect of particulates or corrosive species on the dry pump's performance and the device's reliability over an extended period of operation. However, a Litmas device was used to process 10,882 wafers without any negative effects on the manufacturing process or the mechanical pump (Vartanian et al., 2000).

Litmas Inc. lists the following safety features for their Litmas "Blue" system: 1) Complies with Canadian Standards Association's (CSA's) requirements for 
electronics devices ${ }^{1}$; 2) a user interlock; 3) double containment in the cooling line to prevent cooling fluid from entering the foreline upon dielectric failure of the user interlock; 4) a temperature interlock that turns the system off if there is cooling water failure; and, 5) a circuit breaker designed to trip after an internal short.

Litmas Inc. lists the capital cost of the device as $\$ 15,000$ for large volume orders, and $\$ 25,000$ for small orders with manual water delivery. Based on the evaluation of the device by Tonnis et al. (1995) the cost of ownership is on the order of $\$ 5,000 /$ year over a 5 -year life plus the cost of additive gases. The detailed costs are shown in Table 3. Because of the low cooling and power requirements, utility costs are expected to be only a few hundred dollars per year. The system can be equipped with a manual water fill system for an additional cost of approximately $\$ 2,000$ or with an automatic water-delivery system costing $\$ 4,000-\$ 6,000$. Using water vapor instead of oxygen or hydrogen provides savings in material costs.

As discussed above, the Litmas "Blue" is designed for sub-atmospheric pressures and small flow rates. Another device, the Litmas "Red", is an atmospheric-pressure plasma torch designed for higher flow rates from the exhaust. However, this system has not been independently tested yet.

\subsection{Catalytic Decomposition Systems}

Two catalytic decomposition systems are described as being effective in PFC abatement: a Hitachi system (Cox et al., 2001) and a Guild Associates/Misonix system (Brown et al., 2001). The first has been available for a couple of years,

\footnotetext{
${ }^{1}$ Examples of CSA compliance include minimum clearances between high voltage components and case ground, and installation of cooling water and input power receptacles on opposite faces of the unit.
} 
with about 100 units reported sold so far, whereas the second just became available. Both systems are based on the same configuration (Figure 6).

These systems employ two water scrubbers integrated with a catalytic reactor. The reactor contains a proprietary catalyst to convert PFCs to $\mathrm{CO}_{2}$ and HF. They are installed in-line downstream from the dry pump in etching or CVD processchambers. One scrubber is connected before the catalytic decomposition to remove inorganic water-soluble gases (e.g., $\left.\mathrm{SiF}_{4}\right)$ and particulates, and the second after the catalytic unit to remove HF and other fluorinic species generated at the reaction zone. The PFCs pass in series through an electrically heated prereactor and a catalytic reactor.

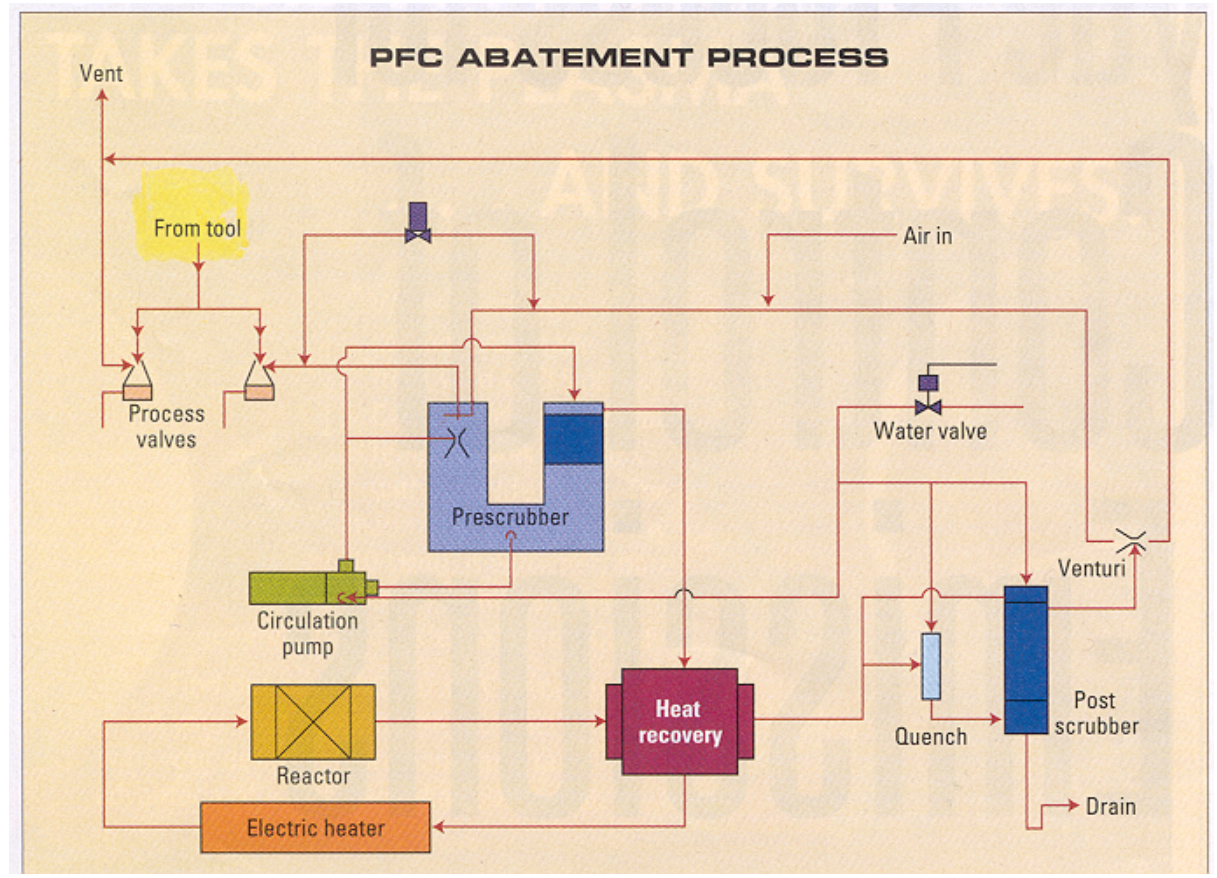

Figure 6. A schematic of ThermoCatalytic PFC abatement systems

The PFC gases are mixed with injected air and water while being heated to a temperature appropriate for the particular mixture (typically $750^{\circ} \mathrm{C}$ ). The PFC/water/air mixture enters the upper section of the catalytic reactor, where the PFCs react with water and air in the presence of the catalyst to form $\mathrm{CO}$ and HF. The $\mathrm{CO}$ is subsequently converted to $\mathrm{CO}_{2}$. Finally, the hot gaseous reaction products $\left(\mathrm{CO}_{2}, \mathrm{HF}, \mathrm{N}_{2}, \mathrm{Ar}\right.$, and $\left.\mathrm{O}_{2}\right)$ enter a quench station where a water spray 
cools them and then pass through a second packed-bed scrubber. The insoluble gases (primarily $\mathrm{CO}_{2}$ and $\mathrm{N}_{2}$ ) are pulled out of the system by a venturi pump and exhausted into the facility's acid-exhaust system. The water-soluble HF is trapped in an aqueous solution that is collected in a wastewater tank. This wastewater is partially recirculated through the system for use in the quench station and pre-reaction scrubber before eventually being discharged to the industrial wastewater system.

\subsubsection{Evaluation of the Hitachi ThermoCatalytic Decomposition System}

The Hitachi SCDS-60 system exhibited an abatement efficiency of $>99.4 \%$ for PFC emissions from a dielectric etch tool (Cox et al., 2001). These emissions included $\mathrm{CF}_{4}, \mathrm{C}_{2} \mathrm{~F}_{6}, \mathrm{CHF}_{3}, \mathrm{C}_{3} \mathrm{~F} 8, \mathrm{C}_{4} \mathrm{~F} 8, \mathrm{C}_{5} \mathrm{~F}_{8}, \mathrm{NF}_{3}, \mathrm{CO}$, and $\mathrm{SF}_{6}$ at 60 slpm gas throughput. PFC concentrations were measured upstream and downstream of the abatement system using Fourier transform infrared spectroscopy (FTIR). The system included water cleaning and recirculation, which reduces water consumption to about $1 \mathrm{gpm}$. Currently Hitachi does not sell the SCDS-60 model, but it sells larger flow models for flows of $120-200$ slpm and multichamber capability. The economics of the 200 slpm system are shown in Table 3.

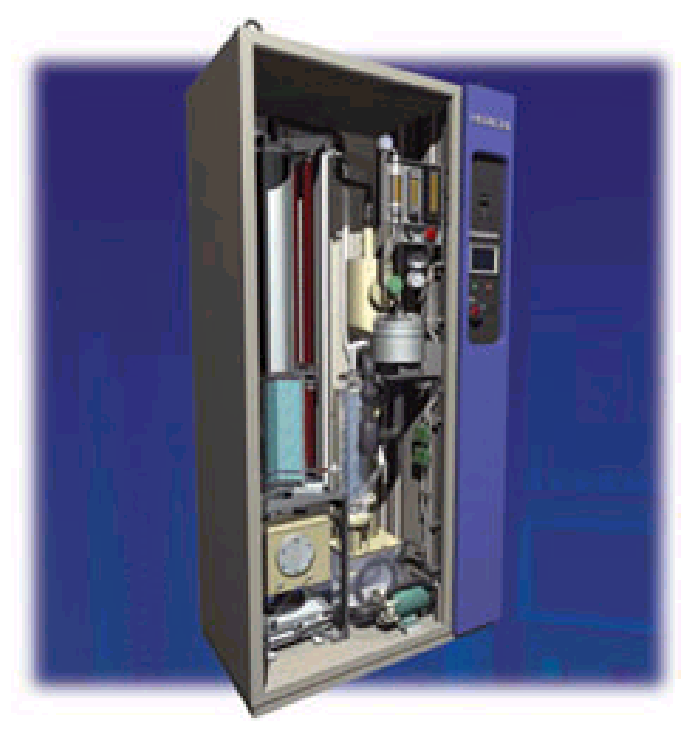

Figure 7. The Hitachi

This system uses less electricity than thermal destruction units; the catalyst's lifetime of the tested unit was reported to be longer than 6.4 months. The manufacturer reports catalyst lifetime of 18 months and $99.9 \%$ efficiency in treating dilute flows (e.g., an exhaust stream of $0.3 \mathrm{lpm} \mathrm{SF}_{6}$, $0.05 \mathrm{lpm} \mathrm{CF}_{4}$, and $0.16 \mathrm{lpm} \mathrm{C}_{4} \mathrm{~F}_{8}$ ).

ThermoCatalytic Abatement System 


\section{DISCUSSION}

There are four primary methods of reducing PFC emissions: process optimization; alternative chemistries; separation and recycling; and point-of-use (POU) abatement. All of them have had some success, but most also have drawbacks.

Optimization often is quite challenging to achieve. It strives to reduce emissions by tuning processes so that they will consume smaller quantities of chemicals, yet still maintain critical processing targets. Alternative chemistries with a low global-warming potential have been used successfully in cleaning CVD chambers, where more degrees of freedom exist. However, optimization did not work well in dry-etch processes that require tight processing controls. $\mathrm{NF}_{3}$ is a viable alternative for chamber cleaning; although it is a greenhouse gas itself, it is utilized almost completely, thereby producing insignificant greenhouse-gas emissions. Using $\mathrm{NF}_{3}$ instead of PFCs in chamber cleaning cuts down dramatically the amount of gas needed and the amount of emissions, and also decreases the cleaning time. In general, $\mathrm{NF}_{3}$ abatement is not required since greater than $99 \%$ of the $\mathrm{NF}_{3}$ is used in the plasma. On the negative side, $\mathrm{NF}_{3}$ is more expensive than most PFCs and, in remote cleaning systems (which add to the capital cost), produces more fluorine that then must be treated. Using $\mathrm{NF}_{3}$ diluted with $\mathrm{He}$ reduces $\mathrm{F}_{2}$ emissions to the levels attained with PFC-based cleaning.

Recovery and recycling methods have not been proven economically feasible.

POU abatement was found to be practical and is becoming the most widely accepted method of eliminating PFC emissions. POU abatement systems are based on either thermal decomposition, plasma discharge, or thermocatalytic decomposition technologies. Three commercial systems were described that were independently tested and are widely implemented in semiconductor 
facilities; Table 3 is a summary comparison. All three effectively destroy PFCs from etching operations, while the Edwards combustion system also efficiently treats such compounds in exhaust streams from chamber operations that carry a lot of particulates. The Hitachi system might also handle streams with particulates in a properly designed pre-reaction scrubber, but this will generate sludge.

The Litmas plasma abatement system differs from thermal abatement methods because it treats the exhaust stream before it is diluted with nitrogen in the dry pump, resulting in lower energy consumption. On the negative side, use of the Litmas device is limited to small-flow-rate exhaust streams from subatmospheric pressure processes. Another type, the Litmas "Red" is available for larger flows and atmospheric conditions, but this has not been tested independently.

The Edwards TPU system is efficacious in abating PFCs from "very dirty" and relatively high-flow-rate streams where the other two are ineffectual. A catalyticconverter system may become plugged from excess solids in a "dirty" exhaust stream and the plasma-destruction equipment is limited to small flow rates by the size of the plasma tube (plasma destruction is effective in 3-inch tubes or smaller). 
Table 3. Summary Comparison of PFC Abatement Systems

\begin{tabular}{|c|c|c|c|}
\hline System & Edwards TPU & Litmas Plasma & Hitachi SCDS-2000 \\
\hline Abatement from & Tool Cleaning & Etching & Etching \\
\hline Number of Inlets & $4^{1}$ & 1 & $4^{1}$ \\
\hline \multirow{2}{*}{\multicolumn{4}{|c|}{ Flow Rates, max tested (slpm per }} \\
\hline & \multicolumn{3}{|c|}{ inlet) } \\
\hline $\mathrm{CF}_{4}$ & 2 & 0.1 & 0.2 \\
\hline Other PFCs \& $\mathrm{SF}_{6}$ & 7 & 0.2 & 0.5 \\
\hline $\mathrm{N}_{2}$ & 47 & -2 & 48 \\
\hline $\mathrm{N}_{2} \mathrm{O}$ & 1 & & \\
\hline $\mathrm{SF}_{6}$ & 25 & 0.1 & 0.3 \\
\hline $\mathrm{SiH}_{4}, \mathrm{~B}_{2} \mathrm{H}_{6}, \mathrm{TMB}, \mathrm{PH}_{3}, \mathrm{GeH}_{4}$, & 0.5 & & \\
\hline $\mathrm{WF}_{6}$ & & & \\
\hline Total Flow & 200 & $?$ & 200 \\
\hline \multicolumn{4}{|l|}{ Concentration, max tested, (vol \%) } \\
\hline PFC & $12 \%$ & & \\
\hline $\mathrm{SF}_{6}$ & $10 \%$ & ? & $10 \%$ \\
\hline $\mathrm{SiH}_{4}$ et al. & $2 \%$ & ? & $0.5 \%$ \\
\hline \multicolumn{4}{|l|}{ Abatement Efficiency (\%) } \\
\hline $\mathrm{CF}_{4}$ & $87-94$ & $92-97$ & $>99.5$ \\
\hline Other PFCs \& $\mathrm{SF}_{6}$ & $>99.5$ & $>99$ & $>99.5$ \\
\hline $\mathrm{SiH}_{4}, \mathrm{~B}_{2} \mathrm{H}_{6}, \mathrm{TMB}, \mathrm{PH}_{3}, \mathrm{GeH}_{4}$, & & & \\
\hline $\mathrm{WF}_{6}$ & $>99.99$ & & \\
\hline Test Period & 6 months & 270 hours & 6 months \\
\hline \multicolumn{4}{|l|}{ Cost } \\
\hline Capital (\$) & $\begin{array}{l}130 \mathrm{~K} \text { (with water } \\
\text { recirculation) }\end{array}$ & $\begin{array}{l}17-27 K^{5}(+2-4 K \\
\text { auto water fill) }\end{array}$ & \\
\hline Installation ${ }^{3}(\$)$ & $20-50 K^{4}$ & $10 \mathrm{~K}$ & $5 \mathrm{~K}$ \\
\hline O\&M (\$/yr) & $8-18 K^{6}$ & $>1 \mathrm{~K}$ & $5 K-10 K^{7}$ \\
\hline Dimensions & $3^{\prime} \times 2^{\prime} \times 6^{\prime}$ & $14^{\prime \prime} \times 12^{\prime \prime} \times 6 "$ & $\sim 3^{\prime} \times 2^{\prime} \times 6^{\prime}$ \\
\hline Weight (lb) & 410 & 17 & \\
\hline \# of Systems Installed & $\sim 1000$ & 135 & $\sim 70$ \\
\hline
\end{tabular}

'Based on total flow capability of 200 slpm and 50 typical slpm pump flow. More or fewer inlets can be manifold to meet the total of $200 \mathrm{slpm}$.

${ }^{2}$ The Litmas LB 1200 is placed before the $\mathrm{N}_{2}$ gas inlet; an Ar flow of 0.15 slpm was used in the evaluation.

${ }^{3}$ The cost of installation includes manifold connections, water, drain, exhaust, CDA, and natural gas (required on Edwards TPU).

${ }^{4}$ The cost of natural gas line hook-up can vary significantly.

5 The low number in the range is reported for large volume orders; the high for small orders. The cost of the Litmas Plasma system does not include a POU scrubber, whereas the other two systems include integrated scrubber(s). It is assumed that no POU scrubber is needed after the Litmas, due to the low PFC flows handled. Fluorine levels of $\sim 50 \mathrm{ppm}$ were measured in the test.

${ }^{6}$ The TPU annual facilities costs are in the order of $\$ 8 \mathrm{~K}$ with the water recirculation unit, and can be as high as $\$ 18 \mathrm{~K}$ without water recirculation.

${ }^{7}$ The low number of this range is based on a catalyst life time of 18 months, which was reported by the manufacturer for dilute flows. The catalyst replacement costs $\$ 6,000$ (Nov. 2001). 
Furthermore, the Edwards TPU system can be used for lowering discharges of silane and other gases (e.g., $\mathrm{NF}_{3}, \mathrm{~B}_{2} \mathrm{H}_{6}, \mathrm{TMB}, \mathrm{PH}_{3}, \mathrm{GeH}_{4}$, and $\mathrm{WF}_{6}$ ), in addition to PFC emissions. Both the exhaust streams of PFCs and of silane can be destroyed in the same TPU, thereby eliminating the need for a separate burn box and scrubber for silane. The Edwards system generates NOx, as does every thermal-destruction system, whereas catalytic destruction, which operates at lower temperatures, does not. The Edwards, operating at the "high-fire" mode required to destroy $\mathrm{CF}_{4}$, emits $150-200$ ppm of $\mathrm{NOx}$, whereas its elimination in the "low-fire" zone produces only 10-20 ppm of NOx. The plasma system can generate NOx but treating the effluent stream before it is mixed with purge $\mathrm{N}$, lowers the production of NOx. The thermal and thermocatalytic abatement systems can be scaled-up to handle higher exhaust volumetric flows than the ones tested so far, whereas the plasma "blue" system cannot be scaled-up.

The PV industry currently uses PFCs in a few manufacturing facilities. However, in accordance with the proactive approach of the industry, alternatives and/or abatement options are investigated early before large-scale manufacturing facilities come online. Although alternatives may not currently exist, tested abatement systems do exist and can be employed at reasonable costs when needed. 


\section{ACKNOWLEDGEMENT}

This report draws heavily from research conducted for the needs of the semiconductor industry. Many thanks to Walter Worth, SEMATECH for valuable discussions.

\section{REFERENCES}

Allgood C. and S. Hsu S., B. Birmingham B., and J. Soucy J., 2000, A Critical Comparison of Chamber Cleaning Processes in an Applied Materials PECVD Tool, http://www.dupont.com/zyron/techinfo/recent/semiconsw2000.html

Beatty C., Sonti K, Williams J., et al., Chamber Clean Optimization for Silicon Carbide Films Using $\mathrm{C}_{3} \mathrm{~F}_{8}$ in a Novellus Concept One PECVD System, Electrochemical Society Proceedings, Vol 2000-7, pp. 33-41.

Brown R. Rosin J. and Thomas C., Catalytic Processes for Control of PFC Emissions, Semiconductor International, June 2001, pp. 209-216.

Chen X, Holber w. and Max P., An Efficient, Highly Reliable Plasma Tool for PFC Abatement, Electrochemical Society Proceedings, Vol 2000-7, pp. 1-8.

Cox J., Koenigseder S. and Decker T., Using a Catalytic Technique to Abate PFC Emissions in a 300-mm Etch Tool, MicroMagazine.com, March 2001.

Cummings W., Dupuis G., Kesari S., Miner D., Trilli K. and Fleming G., The Future of PFC Capture and Recycling Membrane Technology, Semiconductor International, July 1997, 265-272, 1997

Fthenakis V. and Moskowitz P., Plasma Etching: Safety, Health and Environmental Considerations, Progress in Photovoltaics: Research and Applications, 3, 129-134, 1995. 
Gililand T. and Hoover C., Evaluation of Praxair's PFC Capture/Recovery System, Sematech Tech Transfer \#98113600A-ENG, Dec. 21, 1998.

Gompel J. and Walling T., A New Way to Treat Process Exhaust to Remove $\mathrm{CF}_{4}$, Semiconductor International, Sept. 1997, pp. 95-100.

Johnson A., Entley W., Vrtis R, Langan $\mathrm{J}$ and Maroulis P., Optimization of a $\mathrm{C}_{2} \mathrm{~F}_{6}$ Clean for an Apllied Materials' TEOS PECVD Process: Reduced PFC Emissions and Faster Clean Times, Electrochemical Society Proceedings, Vol 2000-7, pp. 21-32.

Kelly R., PFC Capture by Condensation, SESHA Journal, Vol. 15-Spring 2001, 19-24, 2001.

Martinelli L. and Worth W., Global Warming: A white Paper on the Science, Policies and Control Technologies that Impact the US Semiconductor Industry, SEMATECH, March 30, 1994.

Mendicino L., Filipiak S., Brown P., et al., Evaluation of the Applied Materials $\mu$ CLean Technology for DxZ Chamber Clean for PFC Emissions Reduction, Sematech Tech Transfer \#98083547B-TR, Sept. 30, 1998

Ravishankara A., Solomon S., Turnipseed and Warren R., Atmospheric Lifetimes of Long-Lived Halogenated Species, Science, 259, vol. 259, (Jan 8 1993, pp. 194-199.

Tonnis E., Vartanian V., Beu L, Lii T, Jewett R and Graves D., Evaluation of a Litmas "Blue" POU Plasma Abatement Device for PFC Destruction, Sematech Tech Transfer \#98123605A-ENG, Dec. 15, 1999. 
Vartanian V., Beu L., Stephens T., et al., Litmas Plasma Abatement Long-Term Reliability Test, Electrochemical Society Proceedings, Vol 2000-7, pp. 9-20, 2000.

Walling T., Tran A. and Ridgeway, R., Evaluation of an Edwards TPU4214 and an Ecosys Phoenix IV for CF4 Abatement, Sematech Tech Transfer \#970073319A-TR, Sept. 30, 1997.

Worth W., PFC Emissions Reduction Options, SSA $23^{\text {rd }}$ Annual Symposium, New Orleans, April 13-14, 2001

Relevant Web sites:

http://www.epa.gov/globalwarming/index.html

http://www.sematech.org/public/index.htm

http://www.dupont.com/zyron

http://www.bocedwards.com

http://www.abatementsystems.com/

http://www.hitachi.com/ 